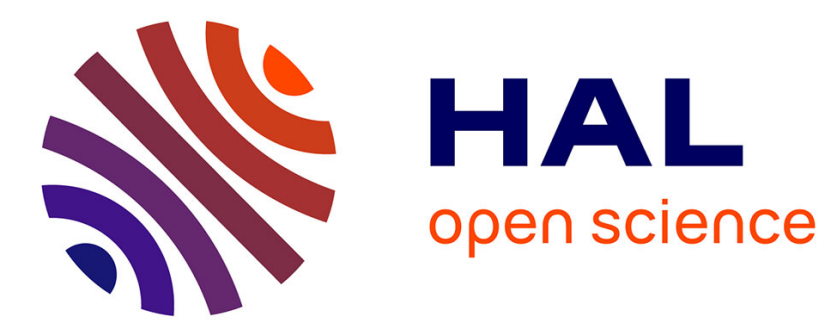

\title{
A dynamic model of irrigation and land-use choice: application to the Beauce aquifer in France
}

\author{
Julia de Frutos Cachorro, Katrin Erdlenbruch, Mabel Tidball
}

\section{To cite this version:}

Julia de Frutos Cachorro, Katrin Erdlenbruch, Mabel Tidball. A dynamic model of irrigation and landuse choice: application to the Beauce aquifer in France. European Review of Agricultural Economics, 2017, 44 (1), pp.99-120. 10.1093/erae/jbw005 . hal-02175818

\section{HAL Id: hal-02175818 \\ https://hal.science/hal-02175818}

Submitted on 16 May 2020

HAL is a multi-disciplinary open access archive for the deposit and dissemination of scientific research documents, whether they are published or not. The documents may come from teaching and research institutions in France or abroad, or from public or private research centers.
L'archive ouverte pluridisciplinaire HAL, est destinée au dépôt et à la diffusion de documents scientifiques de niveau recherche, publiés ou non, émanant des établissements d'enseignement et de recherche français ou étrangers, des laboratoires publics ou privés. 


\title{
A dynamic model of irrigation and land-use choice: application to the Beauce aquifer in France*
}

\author{
Julia de Frutos Cachorro $^{1}$, Katrin Erdlenbruch ${ }^{2}$ and Mabel Tidball ${ }^{3}$ \\ ${ }^{1}$ Department of Agricultural Economics, Faculty of Bioscience Engineering, Ghent University, \\ Coupure Links 653, 9000 Ghent, Belgium. \\ ${ }^{2}$ Irstea, UMR G-EAU, 361 rue Jean François Breton, 34196 Montpellier cedex 5, France, E-mail: \\ katrin.erdlenbruch@irstea.fr (Corresponding author) \\ ${ }^{3}$ INRA, UMR 1135 LAMETA, F-34000 Montpellier, France.
}

June 2016

Article published in the European Review of Agricultural Economics doi: 10.1093/erae/jbw005

\begin{abstract}
We set up a model of land-use and irrigation water choices to assess the impact of dry weather conditions and possible restriction policies on farmers' payoffs in the Beauce area in France. Given the informational context, we construct a dynamic twoperiod model in which farmers make conjectures on the water abstraction by other users and take into account variations in the height of the water-table. We solve the problem using dynamic programming. We simulate different restriction policies, proposed in the literature and tested in the field. We show that these restrictions, although efficient with respect to hydrological criteria, result in serious economic losses for the farmers.
\end{abstract}

Keywords: groundwater management; hydro-agro-economic model; dynamic programming; irrigation; Beauce aquifer.

\section{JEL: C61, Q15, Q25}

${ }^{*}$ We are grateful to Sami Bouarfa, Caroline Lejars, Jean-Louis Fusiller, Nina Graveline, Sylvie Morardet and Farida Ouchiha who helped on various parts of the work. We acknowledge financial support from the ANR project RISECO, ANR-08-JCJC-0074-01. 


\section{Introduction}

In the second half of the 20th century, the increasing use of tube wells and mechanical pumps has led to significant groundwater depletion in many parts of the world (Shah et al. 2007). With the help of irrigation, high performance agricultural production areas have been created above aquifers, contributing to the growing pressure on groundwater resources (Shah et al. 2007). As a consequence, water managers need to counteract dropping groundwater levels to secure water for other uses as well as for future generations. To do so, they may rely on institutions (Ostrom 1990), regulatory tools (Pérez-Blanco and Gómez 2014) or economic instruments, such as pricing and water markets (see for example Easter et al. 1999, Koundouri 2004).

In this article, we focus on the Beauce area, one of the most important agricultural production regions in France, and one of the biggest cereal producing regions in Europe. Not only is the Beauce aquifer a typical example of an aquifer depleted by individual pumping for irrigation, but it is also an interesting example because of the restriction policies already in place. Restrictions in the Beauce area are proportional reductions in farmers' individual quotas and are contingent on the aquifer level. Less precipitation and increasing water demand may render potentially drastic restriction policies necessary (Lejars et al. 2012a,c). The aim of this paper is to evaluate the impact of different restriction policies on farmers' land allocation and irrigation decisions under dry weather conditions.

Similar to the work of Madani and Dinar 2012, we make rather unusual but realistic assumptions about the informational context in which farmers take their decisions. Concerning the time horizon, farmers are assumed to be neither completely myopic, i.e. maximizing their instantaneous welfare, nor completely farsighted, i.e. taking the longterm outcomes of payoffs and resources into account. Concerning the actions of other resource users, they are neither completely smart, i.e. learning about the behavior of other users, nor are they completely ignorant of other resource users' water abstractions. ${ }^{1}$

Completely myopic agents justify the use of static models, and such agents have been extensively used in programming models explaining optimal crop choices (see for example Howitt 1995, Heckelei 2002, Heckelei and Wolff 2003, Graveline et al. 2012 or Graveline and Mérel 2014). Good knowledge of future changes in the resource and farsighted agents justify the use of dynamic resource models, explaining the optimal choice of water use over

\footnotetext{
${ }^{1}$ Madani and Dinar distinguish four possible types of behavior in a non-cooperative common pool resource (CPR) management problem. They state: "ignorant myopic management and smart non-myopic management institutions reflect two extreme cases of anti-ideal and ideal types of users, respectively. Based on the current conditions of the CPRs in practice, $[. .$.$] it is reasonable to claim that most CPR users adopt$ the institutions which are in between the two extremes".
} 
time, and have been extensively used in the resource economics literature (see for example Burt 1967, Gisser and Sánchez 1980, Roseta-Palma 2002, Moreaux and Reynaud 2006, or De Frutos Cachorro et al. 2014). ${ }^{2}$

In this paper, we construct a model in which farmers choose crop allocation and irrigation water volumes. Individual farmers do not consider long-term changes in the resource and are therefore modelled as decision makers with a limited planning horizon. However, when taking their decisions in spring, farmers consider the potential impact of restrictions not only on the spring crop but also on the summer crop. They are hence farsighted over two periods. In addition, farmers in the Beauce area can observe the level of the resource and make conjectures about the total abstraction volume made by other resource users, based on information from the previous years. In contrast to other hydro-economic models in the literature (see for example Britz et al. 2013, Erfani et al. 2014), we presume the farmers have imperfect information on other users' actions but do make some best guesses about their water abstractions. In addition, there is no formal water market that can adjust water demand and supply (but see Erfani et al. 2014 for a model including water markets). Because farmers are somewhat farsighted when restrictions are in place and because they can monitor changes in the resource over the year, we construct a dynamic two-period hydro-agro-economic model.

Situated south-west of Paris, the Beauce aquifer extends over $9700 \mathrm{~km}^{2}$ (see Lejars et al. 2012b). With less than $600 \mathrm{~mm}$ of rainfall per year, it is one of the driest regions in France (see Lejars et al. 2012b). As a consequence, about $50 \%$ of the agricultural land is irrigated (MAAF 2012), mainly with water from the aquifer. The aquifer is also a crucial resource for drinking water in the region. The management of the Beauce aquifer is therefore an important issue that has been addressed through several governance schemes. In particular, since 1995, irrigation restrictions depend on the state of the aquifer and since 1999, individual irrigation quotas have been introduced, which are adjusted every spring through a reduction coefficient calculated as a function of the state of the aquifer. ${ }^{3}$

Future weather conditions may render drastic restrictions necessary. This is why Lejars et al. 2012c discussed the potential impact of restrictions representing $40 \%$ and $70 \%$ of quota in force today. In this paper, we first assess how the farmers adjust to dry weather conditions and what this implies for the aquifer. We then introduce restrictions of $20 \%$, $40 \%$ and $70 \%$ of individual quotas under dry conditions in our model. While Lejars et

\footnotetext{
${ }^{2}$ Other dynamic models exist, e.g. on reservoir management (see for example Vedula and Nagesh Kumar 1996 or Evers et al. 1998), or on the dynamics of agricultural yields (see for example Reynaud 2009 or Knapp and Schwabe 2008), but they do not deal with groundwater management and particularly with the consequence of a drop in the height of the water-table for the cost of extraction.

${ }^{3}$ The aquifer has an average stock of 20 billion $\mathrm{m}^{3}$ but has been subject to quite high inter-annual variations over the last 30 years (see Coz 2000).
} 
al. (2012c) studied such restrictions in focus groups with farmers, we test the impact of such restrictions in an analytical model. Similar stringent restrictions have been found to be necessary in other regions of Europe. For example, Pérez-Blanco and Gómez 2014 reported that drought management plans in the Guadalquivir river basin in Spain lead to restrictions of $30 \%$ when the drought alert index is reached and up to $70 \%$ in emergency situations. Our study shows that, although restrictions are efficient in preserving watertable levels, they result in serious economic losses for farmers, representing almost one third of gross annual value added in the most extreme scenario.

The paper is organized as follows. In Section 2, we present the hydro-agro-economic model and the solution approach we use. In Section 3, we describe the existing data and the transformations we undertook to be able to apply the model to the Beauce study area. We model choices of a representative farm specialized in field crops and sugar beet production, which is one of the four main farm types in the study area. We estimate the water response of the underlying yield functions. We also consider how yield responses and water-use by competitive sectors change, depending on weather conditions. In Section 4, we present the baseline-case, a normal year corresponding to 2010, and results for different scenarios, namely a dry year with no policy intervention, and four policy-scenarios, in which quotas and restrictions are used to cope with dry conditions. In Section 5, we discuss the impact of some key parameters of our model. Finally, in Section 6 we present our conclusions and ideas for further research.

\section{A Model of Irrigation and Land-Use Choice}

\subsection{The Model}

We consider a two-period and $k$-crop model for a representative farm with a surface area $S$. We call $t=0$ the first time period (spring) and $t=1$ the second time period (summer) for which decisions are taken. At the beginning of spring, the farmer chooses the share of land, $\alpha_{k}(t)$, with $0 \leq \alpha_{k}(t) \leq 1$ and the (per hectare) irrigation water volume, $w_{k}(t)$, for each crop $k$ and each period $t$. These are the decision variables. $M$ represents the number of representative farmers in the study area, which covers a total surface area of $S_{b}$ hectares. These farmers share the same aquifer, which is described by the height of the water-table, $H(t)$, which is the state variable. The water-table changes as a function of all the farmers' irrigation decisions (see equation (5)). In the following, we describe all the parameters and variables of the model which are also described in table $1 .{ }^{4}$

\footnotetext{
${ }^{4}$ For the sake of simplicity, whenever possible, we suppress the time indicator in the following.
} 


\section{Name Description}

$S \quad$ Mean surface area of representative farm

$\alpha_{k} \quad$ Share of surface area of crop $k$ (decision variable)

$w_{k} \quad$ Water volume (per hectare) used for crop $k$ (decision variable)

$H \quad$ Water-table height (state variable)

$y_{k} \quad$ Yield water response (per hectare) of crop $k$

$a_{k} \quad$ Coefficient 1 of yield water response of crop $k$

$b_{k} \quad$ Coefficient 2 of yield water response of crop $k$

$x_{k} \quad$ Intercept of yield water response of crop $k$

$p_{k} \quad$ Price of crop $k$

$c_{k}^{o} \quad$ Operating expenses (per hectare) for crop $k$

$c_{k}^{p} \quad$ Pumping costs (per hectare) for crop $k$

$d_{k} \quad$ Coefficient 1 of operating expenses for crop $k$

$e_{k} \quad$ Coefficient 2 of operating expenses for crop $k$

$z \quad$ Cost parameter for maximum pumping height

c Unit energy cost per volume pumped

$\pi \quad$ Gross value added (per period) for representative farm

$\beta \quad$ Discount rate

$\tilde{w} \quad$ Total volume of irrigation water for representative farm

$w^{j} \quad$ Irrigation water used by all other types of farms

$w^{o} \quad$ Water for other uses than irrigation

$W \quad$ Total water extractions for all water uses

$M \quad$ Number of representative farms

$r \quad$ Net average recharge in one period

$\sigma \quad$ Return flow coefficient

$\gamma \quad$ Withdrawal coefficient

$\eta \quad$ Aquifer stock coefficient

$S_{b} \quad$ Total surface are of study area

$H_{0} \quad$ Initial height of water-table

$\bar{\alpha} \quad$ Share of surface are used for summer crop

$\bar{w} \quad$ Minimum amount of water applied to the summer crop

Table 1: List of Variables and Parameters 
First, the (per hectare) yield response to water, $y_{k}$, for each crop, is given by:

$$
y_{k}\left(w_{k}\right)=a_{k} w_{k}-b_{k} w_{k}^{2}+x_{k}
$$

where $a_{k}, b_{k}$ and $x_{k}$ are positive parameters.

Each farmer aims to maximize the present value of gross values added, $\sum_{t} \beta^{t} \pi(t)$, given the price for each crop, $p_{k}$, the discount rate, $\beta$, and variable costs. For per hectare variable costs, we distinguish operating expenses, $c_{k}^{o}$, which depend on the share of surface area allocated to each crop, from pumping costs, $c_{k}^{p}$, which depend on the water-table height and on the per hectare water volume used for each crop. Hence:

$$
\begin{aligned}
c_{k}^{o}\left(\alpha_{k}\right) & =d_{k} \alpha_{k}+\frac{e_{k}}{2} \alpha_{k}^{2}, \\
c_{k}^{p}\left(w_{k}, H\right) & =(z-c H) w_{k},
\end{aligned}
$$

where $d_{k}$ and $e_{k}$ are positive parameters of operating expenses, and $z$ and $c$ positive parameters of the cost of pumping. In particular, the quadratic form of operating expenses is due to implicit management costs associated with a given land allocation. As shown by Carpentier and Letort 2012, quadratic costs occur because of the constraints associated with quasi-fixed inputs (machinery and labor peak loads) and crop rotations (see also Heckelei and Wolff 2003). Concerning the pumping cost function, z measures the marginal costs of maximum possible lift and c the unit energy cost (see for example Gisser and Sánchez 1980). Thus, Gross Value Added in period t is given by:

$$
\pi(t)=\sum_{k} S\left\{\alpha_{k}(t)\left[p_{k} y_{k}\left(w_{k}(t)\right)-c_{k}^{p}\left(w_{k}(t), H(t)\right)\right]-c_{k}^{o}\left(\alpha_{k}(t)\right)\right\}
$$

The water-table height decreases with total extractions, $W$, corrected by the withdrawal coefficient $\gamma$, and increases according to the return flow coefficient $\sigma$ and the net recharge over the period concerned, $r(t)$. The storage capacity of the aquifer is represented by the surface area of the study area, $S_{b}$ and the aquifer stock coefficient, $\eta$. The height of the water-table in the second period thus depends on the height of the water-table in the first period in the following way:

$$
H(t+1)=H(t)+\frac{r(t)-(1-\sigma) \gamma W(t)}{\eta S_{b}}, \quad t=0,1 .
$$

Total extractions are the sum of extractions by representative farms and other extractions:

$$
W(t)=M \tilde{w}(t)+w^{j}(t)+w^{o}(t)
$$

with

$$
\tilde{w}(t)=S \sum_{k} \alpha_{k}(t) w_{k}(t)
$$


the total water volume used by each farmer, $w^{j}(t)$ irrigation water volumes of non-representative farms and $w^{o}(t)$ water extraction for other uses, namely drinking water and industrial uses.

We consider that the representative farm does not know the value added of the other players who share the aquifer. However, the farmer guesses the volume used by other water users, for example, based on the total amount of water used in a previous agricultural campaign. Finally, we assume that the value of the resource at the end of the planning horizon, $V(H(2))$, is constant. This means that the implicit price of the water resource at that time is zero. The farmer's planning horizon is indeed only one agricultural campaign with two irrigation periods and the value of water at the end of these seasons is nil for the production process considered here.

The general problem for the representative farmer is hence the following:

$$
\begin{gathered}
V\left(H_{0}\right)=\max _{\left\{\alpha_{k}(t) \geq 0, w_{k}(t) \geq 0\right\}} \sum_{t} \beta^{t} \pi(t) \quad \text { s.t. } \quad(1) \quad \text { to } \quad(7) \text { with } \\
H(0)=H_{0}, \quad V(H(2))=V_{T} \text { (constant), and } \sum_{k} \alpha_{k}=1 .
\end{gathered}
$$

We use the dynamic programming principle to solve the problem. Consequently, we have to solve the Hamilton-Jacobi-Bellman equation:

$$
V(H(t))=\max _{\left\{\alpha_{k}(t) \geq 0, w_{k}(t) \geq 0\right\}} \pi(t)+\beta V(H(t+1)),
$$

where,

$$
H(t+1)=H(t)+\frac{r(t)-(1-\sigma) \gamma\left[M \sum_{k} \alpha_{k}(t) S w_{k}(t)+w^{j}(t)+w^{o}(t)\right]}{\eta S_{B}}, \quad t=0,1 .
$$

$\pi(t)$ described in (4) and constraints (9) above.

\subsection{A Simpler Case}

In the following, we consider a simpler case representing a typical situation in the Beauce area. We use a model with three crops, of which two are grown in spring. Because there is only one main summer crop, which is grown on a contractually fixed proportion of land, in the following, we assume the case where the share of the summer crop is fixed. The contract also implies that the summer crop cannot be grown without a minimum amount of irrigation. Hence, we have:

$$
\alpha_{1}(0) \geq 0, \quad \alpha_{2}(0) \geq 0, \quad \alpha_{3}(1)=\bar{\alpha}
$$

and consequently:

$$
w_{1}(0) \geq 0, \quad w_{2}(0) \geq 0, \quad w_{3}(1) \geq \bar{w},
$$

and

$$
\alpha_{1}(1)=\alpha_{2}(1)=\alpha_{3}(0)=w_{1}(1)=w_{2}(1)=w_{3}(0)=0 .
$$


Author-produced version of the article published in European Review of Agricultural Economics, 2016, N44(1), p.99-120. The original publication is available at http://erae.oxfordjournals.org Doi: 10.1093/erae/jbw005

\subsubsection{Land Use and Water Volumes in Summer}

We can now solve the dynamic programming problem using backward induction. As $V(H(2))=V_{T}$ (constant), we have:

$$
\pi(1)=S \bar{\alpha}\left(p_{3}\left(x_{3}+a_{3} w_{3}(1)-b_{3} w_{3}(1)^{2}\right)-d_{3}-z w_{3}(1)+c H(1) w_{3}(1)\right)-S \frac{e_{3}}{2} \bar{\alpha}^{2}
$$

We first solve

$$
V(H(1))=\max _{w_{3}(1)} \pi(1)+\beta V_{T}
$$

The necessary condition of optimality is:

$$
\frac{\partial \pi(1)}{\partial w_{3}(1)}=0 \Leftrightarrow S \bar{\alpha}\left(p_{3} a_{3}-2 p_{3} b_{3} w_{3}(1)-z+c H(1)\right)=0
$$

hence:

$$
w_{3}(1)=\frac{p_{3} a_{3}-z+c H(1)}{2 p_{3} b_{3}},
$$

with

$$
\begin{gathered}
H(1)=H_{0}+\frac{r(0)-(1-\sigma) \gamma\left(M S\left(\alpha_{1}(0) w_{1}(0)+\alpha_{2}(0) w_{2}(0)\right)+w^{j}(0)+w^{o}(0)\right)}{S_{B} \eta} \\
\text { and } \alpha_{2}(0)=1-\alpha_{1}(0)-\bar{\alpha} .
\end{gathered}
$$

Note that $p_{3} a_{3}-2 p_{3} b_{3} w_{3}(1)$ is the marginal benefit derived from the summer crop and $z-c H(1)$ is the marginal cost of water-use in summer. Hence, equation (12) describes the optimal irrigation water choice as the one that equalizes marginal benefit and marginal costs for the summer crop. Moreover, given the relation between the water table and irrigation water-use (see equation (13)), marginal costs for water use in summer depend on the optimal irrigation water choice in spring. Substituting (12) and (13) in (10), we can compute the maximum value of the resource in summer as a function of the choices made in spring:

$$
V(H(1))=\pi^{*}(1)+\beta V_{T}
$$

\subsubsection{Land Use and Water Volumes in Spring}

Next, we maximize the value of the resource in spring in $t=0$. We have to solve:

$$
V(H(0))=\max _{\substack{\alpha_{1}(0) \\ w_{1}(0), w_{2}(0)}} \pi(0)+\beta V(H(1))
$$

with

$$
\begin{gathered}
\pi(0)=S \alpha_{1}(0)\left(p_{1}\left(x_{1}+a_{1} w_{1}(0)-b_{1} w_{1}(0)^{2}\right)-d_{1}-z w_{1}(0)+c H_{0} w_{1}(0)\right)-S \frac{e_{1}}{2} \alpha_{1}(0)^{2} \\
+S\left(1-\alpha_{1}(0)-\bar{\alpha}\right)\left(p_{2}\left(x_{2}+a_{2} w_{2}(0)-b_{2} w_{2}(0)^{2}\right)-d_{2}-z w_{2}(0)+c H_{0} w_{2}(0)\right)-S \frac{e_{2}}{2}\left(1-\alpha_{1}(0)-\bar{\alpha}\right)^{2}
\end{gathered}
$$


and $V(H(1))$ described in (14). One necessary condition of optimality is:

$$
\frac{\partial \pi(0)}{\partial \alpha_{1}(0)}+\beta \frac{\partial \pi(1)^{*}}{\partial \alpha_{1}(0)}=0 \Leftrightarrow P(1)-P(2)+\beta \frac{\partial \pi(1)^{*}}{\partial \alpha_{1}(0)}=0
$$

with $\mathrm{P}(1)$ and $\mathrm{P}(2)$ the value added from crops 1 and 2 :

$$
\begin{gathered}
P(1)=S p_{1}\left(x_{1}+a_{1} w_{1}(0)-b_{1} w_{1}^{2}(0)\right)-S d_{1}-S z w_{1}(0)+S c H_{0} w_{1}(0)-S e_{1} \alpha_{1}(0), \\
P(2)=S p_{2}\left(x_{2}+a_{2} w_{2}(0)-b_{2} w_{2}^{2}(0)\right)-S d_{2}-S z w_{2}(0)+S c H_{0} w_{2}(0)-S e_{2}\left(1-\bar{\alpha}-\alpha_{1}(0)\right) .
\end{gathered}
$$

Equation (16) describes the optimal share of land-use used for crop 1 in spring. Notice that this solution depends on the difference between the gains from crop 1 (equation (17)) and crop 2 (equation (18)) and the impact of the choice of land-use in spring, $\alpha_{1}(0)$, on the discounted value of the resource in summer $\beta \frac{\partial \pi^{*}(1)}{\partial \alpha_{1}(0)}$ (see (14)). Clearly, the greater the difference between the gains obtained from crop 1 and 2 , and/or the smaller the irrigation volume used in summer, the greater the share chosen for crop 1.

The other conditions for a maximum are:

$$
\begin{gathered}
\frac{\partial \pi(0)}{\delta w_{1}(0)}+\beta \frac{\partial \pi(1)^{*}}{\partial w_{1}(0)}=0 \Leftrightarrow S \alpha_{1}(0)\left(p_{1} a_{1}-2 p_{1} b_{1} w_{1}(0)-z+c H_{0}\right)+\beta \frac{\partial \pi(1)^{*}}{\partial w_{1}(0)}=0, \\
\frac{\partial \pi(0)}{\partial w_{2}(0)}+\beta \frac{\partial \pi(1)^{*}}{\partial w_{2}(0)}=0 \Leftrightarrow S \alpha_{2}(0)\left(p_{2} a_{2}-2 p_{2} b_{2} w_{2}(0)-z+c H_{0}\right)+\beta \frac{\partial \pi(1)^{*}}{\partial w_{2}(0)}=0 .
\end{gathered}
$$

Following equations (19) and (20), optimal irrigation water volumes for crop 1 (crop 2 respectively) depend on the share of land used for crop 1 (crop 2), the difference between marginal benefits and costs of water use for crop 1 (crop 2) and the value of the resource in summer given the irrigation water choice for crop 1 (crop 2) in spring.

We have a system of three equations: (16), (19) and (20), with three unknowns which we can therefore determine and find $\alpha_{1}^{*}(0), w_{1}^{*}(0)$ and $w_{2}^{*}(0)$. Finally, we have to substitute $\alpha_{1}^{*}(0), w_{1}^{*}(0)$ and $w_{2}^{*}(0)$ in equation (12) to find $w_{3}^{*}(1)$ the optimal irrigation water choice for crop 3 .

At this point, we have only described the optimal interior solution of the problem. In order to take into account corner solutions, we need to consider different cases, depending on whether or not water use quotas and restrictions are implemented (see table 2). Quotas reduce the total water amount available. They can be reduced by a coefficient $\omega(0<\omega \leq$ 1), depending on the water-table level at the beginning of the irrigation season. Without quotas or restrictions, we have to consider the 15 cases in Table 2 . If quotas and restrictions are implemented, we have to consider the additional constraint

$$
S \alpha_{1} w_{1}+S \alpha_{2} w_{2}+S \bar{\alpha} w_{3}=\omega X
$$

for all cases, except cases 9, 14, 15 and the specific reduction coefficient. The optimum is given by the solution (corner or interior solutions) that maximizes $\mathrm{V}(\mathrm{H}(0)$ ). 
Author-produced version of the article published in European Review of Agricultural Economics, 2016, N44(1), p.99-120. The original publication is available at http://erae.oxfordjournals.org Doi: 10.1093/erae/jbw005

\begin{tabular}{c|c} 
Cases & Values \\
\hline Case 1 & $\alpha_{1}=0 \Longrightarrow w_{1}=0$ \\
Case 2 & $\alpha_{2}=0 \Longrightarrow w_{2}=0$ \\
Case 3 & $w_{1}=0$ \\
Case 4 & $w_{2}=0$ \\
Case 5 & $w_{3}=\bar{w}$ \\
Case 6 & $w_{1}=w_{2}=0$ \\
Case 7 & $w_{1}=0$ and $w_{3}=\bar{w}$ \\
Case 8 & $w_{2}=0$ and $w_{3}=\bar{w}$ \\
Case 9 & $w_{1}=w_{2}=0$ and $w_{3}=\bar{w}$ \\
Case 10 & $w_{1}=w_{2}=\alpha_{1}=0$ \\
Case 11 & $w_{1}=w_{2}=\alpha_{2}=0$ \\
Case 12 & $w_{1}=\alpha_{1}=0$ and $w_{3}=\bar{w}$ \\
Case 13 & $w_{2}=\alpha_{2}=0$ and $w_{3}=\bar{w}$ \\
Case 14 & $w_{1}=w_{2}=\alpha_{1}=0$ and $w_{3}=\bar{w}$ \\
Case 15 & $w_{1}=w_{2}=\alpha_{2}=0$ and $w_{3}=\bar{w}$
\end{tabular}

Table 2: Possible Corner Solutions.

\section{Data on the Beauce Area}

Our study area, the "Central Beauce" area, which was defined by Lejars et al. 2012b, occupies an area of 300600 ha of agricultural land and can be considered as representative of the whole Beauce region in terms of farm types. The Beauce region is one of the driest regions in France, with less than $600 \mathrm{~mm}$ rainfall per year. More than half the farms depend on individual water extractions from the Beauce aquifer. Since 1999, the aquifer has a well-established volumetric management system consisting in individual irrigation quotas, which are adjusted each year by a reduction coefficient as a function of water-table levels and are communicated to farmers at the beginning of the irrigation season, (see Petit 2002). Farmers can observe the water-table level in their wells or they can learn about the water-table level from the water-basin manager and official statistics. In addition, each spring, they are informed whether additional restrictions will be introduced in the region. Whether restrictions apply or not depends on the level of the aquifer. Severe restrictions apply when the crisis threshold is reached and some restrictions may even apply earlier, when the alert threshold is reached. In 2010, the crisis threshold was at $110.75 \mathrm{~m} \mathrm{NGF}^{5}$, the alert threshold at $112.19 \mathrm{~m}$ NGF. Relatively high variability of water-table levels led to variations in restrictions ranging from 4.5\% to $55 \%$ from 1999 to the present (see Bouarfa

\footnotetext{
${ }^{5}$ Nivellement Général de la France (NGF) or General Levelling of France is the official levelling measure.
} 
Author-produced version of the article published in European Review of Agricultural Economics, 2016, N44(1), p.99-120. The original publication is available at http://erae.oxfordjournals.org Doi: 10.1093/erae/jbw005

et al. 2011 or Lejars et al. 2012c). In the future, severe restrictions could be necessary under certain climate change assumptions (Lejars et al. 2012c). Following Lejars et al., we test restrictions corresponding to $40 \%$ and $70 \%$ reductions in individual quotas.

In what follows, we describe the agronomic, hydro-geological and economic data we use to inform our model of irrigation and land-use choice. Our baseline case is the year 2010, which corresponds to a year with normal precipitation in the study area. We also consider a scenario of a dry year, with and without restrictions on irrigation water use, for which some of the parameters change.

\title{
3.1 Agronomic Data
}

\subsubsection{Types of Farms}

Based on RGA ${ }^{6}$ land-use data in 2010, Lejars et al. 2012a,b,c, identified four types of field crop farms in the study area. All of them cultivate over $45 \%$ of winter crops (mainly wheat) but differ from each other in the spring or summer crops in which they specialize: sugar beet in the first group, rapeseed in the second, special crops in the third, and maize in the fourth. Here, we focus on the most common type of farm in our study area, which accounts for 679 farmers specialized in field-crops and sugar beet. Land-use of the representative field crops sugar beet farm consists mainly of winter cereals, winter barley and sugar beet, with $48 \%, 17 \%$ and $16 \%$ of the land-use share respectively. The general agronomic data is available in the first part of table 3 and Figure 1.

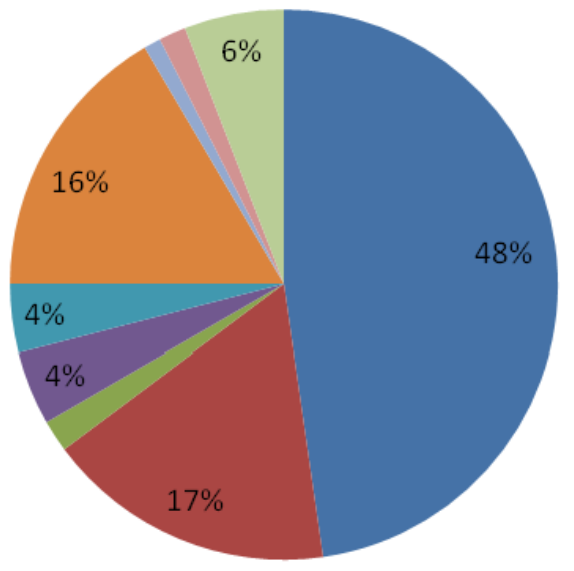

\author{
Winter cereals \\ Spring barley \\ Maize \\ Winter rapeseeds \\ noilseeds \\ Sugar beets \\ Vegetables, seeds \\ Potatoes \\ - Other
}

Figure 1: Representative field crops sugar beets farms in the study area.

\footnotetext{
${ }^{6}$ The General Agricultural Census (French acronym RGA for Recensement Général de l'Agriculture) is a survey conducted every ten years that updates knowledge of the farming sector: number of farms, allocation of farm land...
} 


\begin{tabular}{|c|c|c|c|}
\hline Parameters & Description & Unit & Value \\
\hline$S$ & Surface area of representative farm & ha & 122 \\
\hline$M$ & Number of representative sugar beet farms & unitless & 679 \\
\hline $\bar{\alpha}$ & Share of surface area used for summer crop & unitless & 0.16 \\
\hline $\bar{w}$ & Minimum amount of water applied to the summer crop & $\mathrm{m}^{3} / \mathrm{ha}$ & 1300 \\
\hline$\gamma$ & Withdrawal coefficient & unitless & 1.1 \\
\hline$\sigma$ & Return flow coefficient & unitless & 0 \\
\hline$\eta$ & Aquifer storage coefficient & unitless & 0.08 \\
\hline$w^{o}$ & Water for other uses than irrigation & million $\mathrm{m}^{3}$ & 13.78 \\
\hline$w_{p}^{j}$ & Water needs by other farms in spring & $10^{6} \mathrm{~m}^{3}$ & 78 \\
\hline$w_{s}^{j}$ & Water needs by other farms in summer & $10^{6} \mathrm{~m}^{3}$ & 50 \\
\hline$S_{b}$ & Total surface area of study area & $\mathrm{km}^{2}$ & 3006.6 \\
\hline$H_{0}$ & Initial water-table height & $\mathrm{m}$ & 92.81 \\
\hline$r$ & Net recharge in summer and spring & $\mathrm{m}^{3} /$ season & 0 \\
\hline$p_{1}$ & Price crop 1 (soft wheat) & $€ /$ ton & 109 \\
\hline$p_{2}$ & Price crop 2 (barley) & $€ /$ ton & 95.85 \\
\hline$p_{3}$ & Price crop 3 (sugar beet) & $€ /$ ton & 25.41 \\
\hline$d_{1}$ & Coeff 1 operat. expenses crop 1 & $€ /$ ha & 0 \\
\hline$d_{2}$ & Coeff 1 operat. expenses crop 2 & $€ /$ ha & 0 \\
\hline$d_{3}$ & Coeff 1 operat. expenses crop 3 & $€ /$ ha & 0 \\
\hline$e_{1}$ & Coeff 2 operat. expenses crop 1 & $€ /$ ha & 908 \\
\hline$e_{2}$ & Coeff 2 operat. expenses crop 2 & $€ /$ ha & 780 \\
\hline$e_{3}$ & Coeff 2 operat. expenses crop 3 & $€ /$ ha & 1786 \\
\hline $\mathrm{z}$ & Maximum pumping cost & $€ / \mathrm{m}^{3}$ & 0.02912 \\
\hline c & Marginal pumping cost & $€ / \mathrm{m}^{3 *} \mathrm{~m}$ & 0.000224 \\
\hline$V_{T}$ & Final value of resource & $€$ & 0 \\
\hline$\beta$ & Discount rate per period & unitless & 0.05 \\
\hline
\end{tabular}

Table 3: Agronomic, hydrogeologic and economic parameter values for the baseline case.

\subsubsection{Yield Response to Water}

We compute the yield response to water based on simulation data from the agronomic PILOTE Model (see Mailhol et al. 2011). The data accounts for the water balance in the irrigation season (rain, real evapotranspiration (ETR) and irrigation at different dates) and for the yields of different types of crops and soil, for the period 1997-2001. We aggregate data using different regressions according to the type of crop, the type of soil and weather 
Author-produced version of the article published in European Review of Agricultural Economics, 2016, N44(1), p.99-120. The original publication is available at http://erae.oxfordjournals.org Doi: 10.1093/erae/jbw005

conditions. Regression results are given in Tables 10-12 in the Appendix. We focus on results for average/deep soil, which is the most common soil found on specialized sugar beet farms, and on normal and dry weather conditions. Weather conditions are defined as a function of efficient rainfall (rain minus real evapotranspiration) and computed for the most representative crop in each irrigation season, i.e. wheat in spring and sugar beet in summer. In spring, dry conditions correspond to an ETR $\leq-60 \mathrm{~mm}$ and normal conditions to an ETR between $-60 \mathrm{~mm}$ and $35 \mathrm{~mm}$. In summer, the dry condition corresponds to an ETR $\leq-220 \mathrm{~mm}$ and normal conditions to an ETR between $-220 \mathrm{~mm}$ and $-120 \mathrm{~mm}$.

We find that the quadratic relationship between water and yields gives the overall best results, which is in line with results in the literature (see for example Bozkurt et al. 2006 or Ali 2011 for a survey). We also tested linear and cubic relationships but the fit was less good. Note that we use simulated data as the basis for our regressions. All the scenarios we use are assumed to be equiprobable. We can therefore compare the goodness of fit of different model specifications. The values of the regression coefficients are listed in table 4 .

\begin{tabular}{l|l|l|c|c} 
Coefficients & Description & Unit & \multicolumn{2}{|c}{ Values } \\
& & & in a normal year & in a dry year \\
\hline$x_{1}$ & Intercept for wheat & ton $/$ ha & 9.415315 & 7.144896 \\
$x_{2}$ & Intercept for barley & ton $/$ ha & 7.238088 & 5.876013 \\
$x_{3}$ & Intercept for sugar beet & ton $/$ ha & 65.02174 & 42.94781 \\
$a_{1}$ & coef. 1 for wheat & ton $/ \mathrm{m}^{3}$ & 0.0031337 & 0.0051176 \\
$a_{2}$ & coef. 1 for barley & ton $/ \mathrm{m}^{3}$ & 0.002735 & 0.004653 \\
$a_{3}$ & coef. 1 for sugar beet & ton $/ \mathrm{m}^{3}$ & 0.0325382 & 0.0554281 \\
$b_{1}$ & coef. 2 for wheat & ton.ha $/ \mathrm{m}^{3} \cdot \mathrm{m}^{3}$ & 0.00000171 & 0.00000214 \\
$b_{2}$ & coef. 2 for barley & ton.ha $/ \mathrm{m}^{3} \cdot \mathrm{m}^{3}$ & 0.00000125 & 0.00000199 \\
$b_{3}$ & coef. 2 for sugar beet & ton.ha $/ \mathrm{m}^{3} \cdot \mathrm{m}^{3}$ & 0.00000743 & 0.0000141 \\
\hline
\end{tabular}

Table 4: Estimated Coefficients of Yield Function for Normal and Dry Year.

\subsection{Hydro-geological Data}

We use hydro-geological data from Graveline 2013 for the Central Beauce part of the aquifer. For our study, the withdrawal coefficient, the return flow coefficient, the aquifer storage coefficient come from Graveline 2013 and water withdrawals for other uses than irrigation from Lejars et al. 2012b. The water needs of other types of farms in spring and summer come from Lejars et al. 2012a and the total surface area corresponds to the Central Beauce part of the aquifer. The initial water table height for the baseline scenario 
is the one recorded in Spring $2010{ }^{7}$ The initial water-table height in our example is thus $0.62 \mathrm{~m}$ above the alert threshold. Next, we set the net recharge in summer and spring to zero, as most recharge takes place in winter. Finally, water-table heights and withdrawals by other types of farms vary with the scenario. A summary of all these values is presented in the second part of table 3 and in table 5 . All initial water-table heights for restriction scenarios are under the crisis threshold of $110.75 \mathrm{~m}$ NGF. A realistic assumption is that higher restriction scenarios go with lower initial water-table heights.

\begin{tabular}{c|c|c|c|c|c} 
Parameters & Dry year & Quota & $20 \%$ restrict. & $40 \%$ restrict. & $70 \%$ restrict. \\
\hline$H_{0}$ & 92.81 & 92.81 & 74.25 & 55.67 & 27.84 \\
$w_{p}^{j}$ & 97 & 78 & 61 & 47 & 26 \\
$w_{s}^{j}$ & 56 & 50 & 36 & 38 & 41
\end{tabular}

Table 5: Initial water-table levels $H_{0}$ (in $\mathrm{m}$ ) and irrigation water volumes (in $10^{6} \mathrm{~m}^{3}$ ) for other farms in spring, $w_{p}^{j}$, and summer, $w_{s}^{j}$, depending on weather and restriction scenarios.

\subsection{Economic Data}

We use economic data from several sources, which are summarized in the thrird part of table 3. Prices for wheat and barley come from the national agency FranceAgriMer (2012) and price of sugar beet from sugar beet producer organizations (CGB 2009). Operating expenses come from the farm data-base network ROSACE (2010). Because we do not have enough data to regress operating expenses on farm area, we attribute all operating expenses to the quadratic term. Pumping costs correspond to the cost of energy required to pump water to the topsoil. For typical pump capacities of around $50 \mathrm{~m}^{3} / \mathrm{h}, 0.136 \mathrm{~kW}$ is required to lift one $\mathrm{m}^{3}$ one meter. Considering pump efficiencies of $85 \%^{8}$ and energy costs of 0.07 euros $/ \mathrm{kWh}$, we obtain marginal pumping costs of 0.000224 euros $/ \mathrm{m}^{3 *} \mathrm{~m}$. For the largest potential pumping distance (considering the mean surface elevation to be $150 \mathrm{~m}$ above sea level and the deepest point of the aquifer to be $20 \mathrm{~m}$ above sea level) we obtain maximal (marginal) pumping costs of $z=0.02912$ euros per $\mathrm{m}^{3}$. Note that we do not consider neither water taxes or investments or payoffs for irrigation equipment. Therefore, our pumping costs correspond to a minimum bound. The final value of the resource is set to zero. Indeed, individual farmers do not internalize the consequences of long-term changes in the water-table. Finally, the discount rate is set at $5 \%$ for each period considered. ${ }^{9}$

\footnotetext{
${ }^{7}$ Water-table heights are measured in meters. Referring to the General Levelling of France, $92.81 \mathrm{~m}$ corresponds to $112.81 \mathrm{~m}$ NGF because the bottom of the water table is $20 \mathrm{~m} \mathrm{NGF}$.

${ }^{8}$ Personal communication from an expert in the field. Pump efficiencies in the Beauce area are high compared to those in other areas.

${ }^{9}$ This corresponds to a double-digit annual discount rate. Empirically elicited discount rates may be even higher.
} 


\section{Model Results for the Beauce Area}

\subsection{Results for the Baseline Case: A Normal Year}

\begin{tabular}{c|c|c|c|c} 
Variables & Description & Unit & Baseline & Dry Year \\
\hline$\alpha_{1}$ & Share for wheat & unitless & 0.60 & 0.56 \\
$\alpha_{2}$ & Share for barley & unitless & 0.24 & 0.28 \\
$w_{1}$ & Volume of water for wheat & $m^{3} /$ ha & 894 & 1178 \\
$w_{2}$ & Volume of water for barley & $m^{3} / \mathrm{ha}$ & 1059 & 1147 \\
$w_{3}$ & Volume of water for sugar beet & $m^{3} / \mathrm{ha}$ & 2167 & 1954 \\
$\tilde{w}$ & Total water volume & $m^{3}$ & 138782 & 157800 \\
$V(H(0))$ & Gross annual value-added & Euros & 89717 & 84043 \\
\hline$M \tilde{w}$ & Total water of sugar beet farms & $10^{6} \mathrm{~m}^{3}$ & 94.23 & 107.15 \\
$H_{1}$ & Aquifer level by end of spring & $\mathrm{m}$ & 92.09 & 91.93 \\
$H_{2}$ & Aquifer level by end of summer & $\mathrm{m}$ & 91.67 & 91.49 \\
$H_{0}-H_{2}$ & Decrease in the aquifer level & $\mathrm{m}$ & 1.14 & 1.32 \\
\hline
\end{tabular}

Table 6: Dry year compared to baseline case.

Table 6 (second last column) shows the results of the simulation of the baseline case, a normal year corresponding to 2010. The representative sugar beet farmer chooses to allocate $60 \%$ of his/her land to wheat and $24 \%$ to barley, $16 \%$ being used for sugar beet by assumption. Wheat is irrigated with $894 \mathrm{~m}^{3}$ per hectare, barley with $1059 \mathrm{~m}^{3}$ per hectare, and sugar beets with $2167 \mathrm{~m}^{3}$ per hectare, leading to a total water volume of 138782 $\mathrm{m}^{3}$ for one farm and 94.23 million $\mathrm{m}^{3}$ for all the field-crop sugar beet farms. This lowers the height of the water-table from the initial $92.81 \mathrm{~m}$ to $92.09 \mathrm{~m}$ by the end of spring and to $91.67 \mathrm{~m}$ by the end of summer. Note that this water-table level (which corresponds to $111.67 \mathrm{~m} \mathrm{NGF}$ ) is above the crisis threshold (110.75 m NGF) that would lead to severe restrictions. Overall, a representative farm generates a gross annual value added of 89717 euros.

\subsection{Results for a Dry Year}

Table 6 compares simulation results for a dry year with the baseline case. Because the share of the summer crop is fixed, $16 \%$ of land is still allocated to sugar beet, that is $\bar{\alpha}=0.16$. However, the allocation of spring crops changes: compared to the baseline case, the representative farmer chooses to allocate less land to wheat (56\% compared to $60 \%$ ) and more to barley ( $28 \%$ compared to $24 \%$ ). The intuition behind this change is that wheat is more sensitive to drought than barley, because yields are more responsive to water scarcity. This can be checked by computing the marginal productivity of water (MPW) 
at optimal values, in normal and dry years. First, the MPW value for wheat decreases by around 70 euros $/ \mathrm{m}^{3}$ per ha while the MPW for barley decreases by only around 13 euros $/ \mathrm{m}^{3}$. Moreover, the difference in MPW between wheat and barley is around 346 euros $/ \mathrm{m}^{3}$ per ha in a normal year and 288 euros $/ \mathrm{m}^{3}$ per ha in a dry year. This explains the change in the farmers' choice of land-use.

Next, total irrigation water volume increases by $19000 \mathrm{~m}^{3}$. This is due to an increase in both wheat and barley irrigation $\left(1178 \mathrm{~m}^{3} /\right.$ ha compared to $894 \mathrm{~m}^{3} /$ ha for wheat, 1147 $\mathrm{m}^{3}$ /ha compared to $1059 \mathrm{~m}^{3} /$ ha for barley), while irrigation for sugar beets is reduced. The resulting total water volume of a representative farm increases in dry conditions and amounts to $157800 \mathrm{~m}^{3}$ (compared to $138782 \mathrm{~m}^{3}$ in the normal year). This leads to a bigger drop in the water-table, to $91.49 \mathrm{~m}$ by the end of summer (compared to $91.67 \mathrm{~m}$ in the normal year), which corresponds to a drop of $1.32 \mathrm{~m}$. Most of this additional decrease is due to withdrawals in spring. While in a normal spring, the water-table height was reduced by $0.72 \mathrm{~m}$, in a dry spring, it is reduced by $0.88 \mathrm{~m}$, i.e. by $0.16 \mathrm{~m}$. Finally, despite these adaptations, gross annual value-added for the representative farmer decreases only slightly (by 5674 euros) from 89717 euros in the normal year to 84043 euros in a dry year.

\subsection{Results for a Dry Year With Restriction Policies}

We now introduce restriction policies. In the study area, individual quotas are in place. We first analyze the case in which the quota restricts the water volume to amounts in a normal year. Quotas can be changed into restrictions in dry years when the level of the aquifer is low. Table 7 illustrates how the introduction of these policies changes the results. We consider four scenarios: the use of quotas alone and restrictions corresponding to $20 \%, 40 \%$ and $70 \%$ of the quotas. Lejars et al. 2012c considered the $40 \%$ and the $70 \%$ restrictions as possible for future water policies. Graveline and Mérel 2014 considered 10\% and $30 \%$ as policy scenarios in a model on the Beauce aquifer. We hence add the $20 \%$ restriction as a less extreme scenario. In all our restriction scenarios, the initial water-table levels are set below the crisis threshold, justifying policy intervention.

Let us first compare results for a dry year without restrictions to results for a dry year with restriction policies (see Tables 6 and 7). Concerning land use allocation, the use of policies lead to lower land-use shares allocated to wheat and higher shares to barley. Land-use shares of sugar beet are fixed and hence not adjusted. Concerning the irrigation strategy, when restriction policies are implemented, the farmer has access to a smaller total water volume. Priority is then given to the contractual summer crop: sugar beet, for which a minimum amount of irrigation is required by contract, see Bouarfa et al. 2011. Optimal results show that volumes for wheat and barley are greatly reduced. With a 


\begin{tabular}{c|c|c|c|c|c|c}
\multirow{2}{*}{ Var. } & Description & Unit & \multicolumn{4}{|c}{ Restriction Policies } \\
& & & Quota & $20 \%$ & $40 \%$ & $70 \%$ \\
\hline$\alpha_{1}$ & Share for wheat & unitless & 0.56 & 0.56 & 0.55 & 0.53 \\
$\alpha_{2}$ & Share for barley & unitless & 0.28 & 0.28 & 0.29 & 0.31 \\
$w_{1}$ & Volume of water for wheat & $m^{3} /$ ha & 1121 & 870 & 621 & 251 \\
$w_{2}$ & Volume of water for barley & $m^{3} /$ ha & 1077 & 768 & 460 & 3 \\
$w_{3}$ & Volume of water for sugar beet & $m^{3} /$ ha & 1300 & 1300 & 1300 & 1300 \\
$\tilde{w}$ & Total water volume & $m^{3}$ & 138782 & 111025 & 83269 & 41634 \\
$V(H(0))$ & Gross annual value added & Euros & 83811 & 81090 & 75360 & 61175 \\
\hline$M \tilde{w}$ & Total water of sugar beet farms & $10^{6} \mathrm{~m}^{3}$ & 94.23 & 75.39 & 56.54 & 28.27 \\
$H_{0}-H_{2}$ & Decrease in the aquifer level & $\mathrm{m}$ & 1.14 & 0.91 & 0.77 & 0.56 \\
\hline
\end{tabular}

Table 7: Results of simulation for a dry year with restrictions.

restriction of $20 \%$ (respectively $40 \%$ ) the volume of water for wheat is reduced to 870 (respectively 621) $\mathrm{m}^{3}$ per hectare (compared to $1178 \mathrm{~m}^{3}$ per hectare without restrictions) and for barley to 768 (respectively 460) $\mathrm{m}^{3}$ per hectare (compared to $1147 \mathrm{~m}^{3}$ per hectare without restriction). The volume of water for barley is reduced more than for wheat, as wheat requires more water than barley. This is in line with results reported by Graveline and Mérel 2014. With a restriction of $70 \%$, barley is cultivated under dryland farming conditions. Indeed, an amount of $3 \mathrm{~m}^{3}$ per hectare is negligible as the volume applied in one water turn corresponds roughly to $55 \mathrm{~m}^{3}$ per hectare. Overall, water volume reductions are quite important, ranging for instance between $26 \%$ and $33 \%$ of dry year amounts in the $20 \%$ restriction scenario. Graveline and Mérel 2014 find water volume reductions that are smaller than $9 \%$ for a $30 \%$ restriction scenario (intensive margin) but report the move to less water intensive crops (extensive margin) already for $10 \%$ and $30 \%$ restrictions scenarios. Overall, total water volumes decrease to 28.27 (75.39 and 56.54) million $\mathrm{m}^{3}$ in the $70 \%$ (20\% and $40 \%$ ) restriction scenarios. Not surprisingly, restricting total water use has a beneficial effect on the height of the water-table, which drops by about 0.91 $\mathrm{m}(0.77 \mathrm{~m})$ with a restriction of $20 \%$ (respectively $40 \%$ ) and by only $0.56 \mathrm{~m}$ in the most extreme scenario. Restrictions lead to changes in water-table levels of 1-2\%. However, such apparently slight variations correspond to large volumes of water, between 0.2 and 0.4 million $\mathrm{m}^{3} .{ }^{10}$ Moreover, repeated withdrawals of $1-2 \%$ can lead to substantial drops in the water-table level over longer time horizons - except when winter recharge is high. On the other hand, restrictions reduce gross annual value added: compared to the case in which only quotas apply, gross annual value added is reduced by about 2721 euros

\footnotetext{
${ }^{10}$ For comparison, the distance between the alert threshold and the crisis threshold, which is $1.44 \mathrm{~m}$ corresponds to a $1.28 \%$ drop in water-table levels.
} 
Author-produced version of the article published in European Review of Agricultural Economics, 2016, N44(1), p.99-120. The original publication is available at http://erae.oxfordjournals.org Doi: 10.1093/erae/jbw005

in the least restrictive scenario, 8451 euros with a $40 \%$ restriction, and 22637 euros with a $70 \%$ restriction. Such losses correspond to $3 \%, 10 \%$ and $27 \%$ of the gross annual value added compared with when only quotas apply. For comparison, Lejars et al. 2012a found reductions of $10 \%$ and $21 \%$ of gross production under the $40 \%$ and $70 \%$ restriction scenarios, which is very close to our results. In contrast, Graveline and Mérel 2014 report very moderate reductions in profits for the $30 \%$ restriction scenario of a regional Beauce model. In line with our results, Reynaud 2009 or Bouarfa et al. 2011 find again important revenue reductions in their respective case studies. This underlines the fact that although restrictions adequately preserve groundwater levels, they have a significant impact on the farmer's economic situation in the short term, even assuming that he/she adapts optimally to the dry situation. A policy maker could thus count on abundant winter recharge (which can exceed $1.5 \mathrm{~m}$ in wet years) to avoid too high economic losses for farmers, (see Bruand et al. 1997 for data on recharge).

To summarize, we can confirm three general features of adaptation in the face of drought and restriction policies: first, land-use is affected by a reduction in the share of the most sensitive crop and an increase in the share of the less sensitive crop. Second, the total volume of irrigation water for all crops is reduced. Third, in each scenario, lowest water volumes are allocated to the less productive barley crop, higher volumes to the more water sensitive wheat crop and highest volumes to the contractual summer crop. We can also summarize the economic impacts of our simulations. The combined effect of a dry year and restrictions leads to very serious economic losses for the farmers: for example $10 \%$ (16\%) of gross annual value added with a 20\% (40\%) restriction, corresponding to 8627 euros (14 357 euros). The quota only policy leads to a loss of $7 \%$ of gross annual value added (or 5906 euros). The $70 \%$ restriction in quota volumes would lead to a $32 \%$ loss of gross annual value added. Concerning the level of the aquifer, restriction policies show lower aquifers than the baseline case, because initial aquifer levels were intentionally set very low when stringent restrictions are in place. By assumption, there is no recharge in spring and summer, and hence no restriction can enable recovery of the resource within a year. However, we can measure the performance of different restriction policies with respect to the drop in water-table levels they trigger. We can see that the more stringent the restriction, the smaller the drop in the aquifer level during the irrigation campaign. This confirms the importance of the implementation of restriction policies to preserve the resource. 


\section{Discussion of Key Parameters}

Finally, we need to analyze the importance of different parameters in the simulation results. ${ }^{11}$ One major limit of the model is the lack of information to estimate the quadratic function that represents operating costs. As final results could be driven by the choice of this cost function, we designed some scenarios with different operating cost parameters. These different scenarios are simulated in such a way that the marginal unitary cost per crop is the same, as can be seen in Table 8 .

\begin{tabular}{c|c|c|c|c|c|c} 
Var. & \multicolumn{2}{|c|}{ Baseline } & \multicolumn{2}{|c|}{ Scenario 1 } & \multicolumn{2}{|c}{ Scenario 2 } \\
\hline & $d_{1}=0$ & $e_{1}=908$ & $d_{1}=908 / 3$ & $e_{1}=2 * 908 / 3$ & $d_{1}=908 / 2$ & $e_{1}=908 / 2$ \\
& $d_{2}=0$ & $e_{2}=780$ & $d_{2}=780 / 3$ & $e_{2}=2 * 780 / 3$ & $d_{2}=780 / 2$ & $e_{2}=780 / 2$ \\
& $d_{3}=0$ & $e_{3}=1786$ & $d_{3}=1786 / 3$ & $e_{3}=2 * 1786 / 3$ & $d_{3}=1786 / 2$ & $e_{3}=1786 / 2$ \\
\hline$\alpha_{1}$ & 0.60 & 0.68 & 0.73 \\
$\alpha_{2}$ & 0.24 & 0.18 & 0.11 \\
$w_{1}$ & 894 & 894 & 894 \\
$w_{2}$ & 1059 & 1059 & 1059 \\
$w_{3}$ & 2167 & 2167 & 2167 \\
$\tilde{w}$ & 138782 & 137431 & 136082 \\
$V(H(0))$ & 89717 & 67266 & 56504 \\
\hline$M \tilde{w}$ & 94.23 & 93.32 & 92.4 \\
$H_{0}-H_{2}$ & 1.14 & 1.14 & 1.14 \\
\hline
\end{tabular}

Table 8: Results accounting for different operating costs for each crop.

We observe significant changes in the share of land allocated to each crop and in the gross value added obtained by each farmer. For example, in scenario 2 in which the marginal unitary cost for each crop is shared equally between the linear and quadratic parameters, the share of land allocated to wheat (respectively to barley) increases (respectively decreases) by 13 points compared with the baseline scenario. Moreover, the gross value-added decreases by 33213 euros from the baseline scenario to the second scenario, which corresponds to an economic loss of $37 \%$. However, the simulation results provide some hints for the validation of our model. First, total volumes of water used by the farm do not vary significantly between scenarios (less than $2 \%$ ). This implies that changes in water-table levels are very low between scenarios. Concerning economic outputs, the values in the baseline scenario are more realistic, as reported in the different studies conducted in the study area (cf. Lejars et al. 2012b,c).

Next, in our analysis, we use estimated parameter values, $a_{k}, b_{k}$ and $x_{k}$, which contain

\footnotetext{
${ }^{11}$ We thank two anonymous referees for discussions on an earlier version of this section.
} 


\begin{tabular}{|c|c|c|c|c|c|}
\hline Variables & Description & Unit & Baseline & Dry Year & T-test \\
\hline$\alpha_{1}$ & Share for wheat & unitless & $\begin{array}{c}0.60 \\
(0.07)\end{array}$ & $\begin{array}{c}0.58 \\
(0.17)\end{array}$ & $* *$ \\
\hline$\alpha_{2}$ & Share for barley & unitless & $\begin{array}{c}0.24 \\
(0.07)\end{array}$ & $\begin{array}{c}0.26 \\
(0.17)\end{array}$ & ** \\
\hline$w_{1}$ & Water volume for wheat & $m^{3} /$ ha & $\begin{array}{c}986 \\
(409)\end{array}$ & $\begin{array}{l}1440 \\
(764)\end{array}$ & $* *$ \\
\hline$w_{2}$ & Water volume for barley & $m^{3} /$ ha & $\begin{array}{l}1174 \\
(454)\end{array}$ & $\begin{array}{l}1401 \\
(580)\end{array}$ & $* *$ \\
\hline$w_{3}$ & Water volume for sugar beet & $m^{3} /$ ha & $\begin{array}{l}2225 \\
(608)\end{array}$ & $\begin{array}{l}2026 \\
(436)\end{array}$ & $* *$ \\
\hline$\tilde{w}$ & Total water volume & $m^{3}$ & $\begin{array}{l}154392 \\
\left(\begin{array}{ll}40 & 809\end{array}\right)\end{array}$ & $\begin{array}{l}196985 \\
(73219)\end{array}$ & $* *$ \\
\hline$V(H(0))$ & Gross annual value-added & Euros & $\begin{array}{l}92 \quad 381 \\
\left(\begin{array}{ll}8 & 033\end{array}\right)\end{array}$ & $\begin{array}{c}98937 \\
\left(\begin{array}{ll}36 & 044\end{array}\right)\end{array}$ & $* *$ \\
\hline$H_{1}$ & Aquifer level at the end of spring & $\mathrm{m}$ & $\begin{array}{l}92.04 \\
(0.12)\end{array}$ & $\begin{array}{l}91.81 \\
(0.23)\end{array}$ & $* *$ \\
\hline$H_{2}$ & Aquifer level at the end of summer & $\mathrm{m}$ & $\begin{array}{l}91.62 \\
(0.13)\end{array}$ & $\begin{array}{l}91.37 \\
(0.23)\end{array}$ & $* *$ \\
\hline
\end{tabular}

Table 9: Mean simulated values (with standard errors) and 95\% confidence intervals in the T-test comparing sample means. $\left.{ }^{* *}\right)$ indicates cases where $\mathrm{H} 0$ of equal means is rejected. 
uncertainty. We therefore conduct a sensitivity analysis with respect to these parameter values. More precisely, we draw 10000 parameter values in a normal law with standard errors as estimated in the regressions shown in Tables 10-12. Results for normal and dry year scenarios ${ }^{12}$ are given in Table 9.

We can see that land-use changes, as described in our example based on the year 2006, are robust to changes in parameters. Likewise, volumes of water increase for wheat and barley and decrease for the summer crop in the dry scenario, like in our example. Moreover, at the end of spring and summer, the levels of the aquifer are significantly lower under dry conditions than in a normal year. However, gross annual value added according to the uncertainty analysis is greater in a dry year than in a normal year, in contrast to our example. This is probably due to a greater decrease in the yield of the contractual summer crop in our example. Results for the total water volumes are also robust as there is an increase in the dry scenario compared to the normal scenario. The implementation of restriction policies in dry years are then justified.

Finally, we ran other simulations with different values for prices, pumping costs and parameters of the dynamics of the resource. ${ }^{13}$ For example cereal crop prices are key parameters in the economic model. Increasing the price of barley above that of wheat leads to a significant decrease in the share of land allocated to wheat (- 20 points). Doubling cereal prices leads to higher revenues $(+128$ points), but does not influence the state of the aquifer at the end of summer. Doubling the price of sugar beet leads to higher irrigation water volumes used for this crop. Results are less sensitive to an increase in pumping costs. Pumping costs have to be multiplied by at least ten to result in significant changes in the water volumes used and revenues obtained. Finally, a variation in hydrological parameters, for example in water volumes applied by other users or the total surface area of the study area, does not impact individual irrigation and land-use choices but plays an important role in aquifer levels.

\section{Conclusion}

In this paper, we assess the impact of dry weather conditions and restriction policies in the Beauce aquifer in France. To this end, we built a dynamic hydro-agro-economic model to simulate the choice of land-use and irrigation volumes made by farmers. We needed a dynamic model because we wanted to assess restriction policies that apply in spring and in summer, but which the farmers learn about and take into account at the beginning of spring. The dynamic effect is not very large in our model, because pumping costs are

\footnotetext{
${ }^{12}$ Sensitivity analyses have also been made for results of the dry year scenarios with restriction policies in Table 6. Results of these analyses are available from authors upon request.

${ }^{13}$ More detailed results are available upon request.
} 
very low and the aquifer is very large. If the model were to be used in other study areas, the dynamic effect would be increasingly relevant. However, with large surface areas, like Central Beauce, small drops in the level of the water-table lead to major reductions in water volumes and may harm the whole agricultural sector. Specifically, the estimated $1 \%$ to $2 \%$ drops in the level of the water table during the irrigation period correspond to water volumes of between 0.2 and 0.4 million $\mathrm{m}^{3}$. The main contribution of the paper is assessing the impact of dry weather conditions and water restrictions on farmers' decisions concerning optimal land-use and irrigation. We first consider a dry year scenario, in which there is an increase in water demand. We then consider a dry year scenario with different restriction policies. We show that, first, land-use strategies in the face of droughts consist in decreasing the share of the most sensitive crop and increasing the share of the less sensitive crop. Second, total irrigation water volumes may increase in absence of restrictions but are reduced when restrictions are implemented. Third, in the case of restrictions, water volumes are reduced in quite important proportions (with reduction greater than 26\%). Fourth, with restrictions, lowest water volumes are allocated to the less productive barley crop, higher volumes to the more water sensitive wheat crop and highest volumes to the contractual summer crop. Lastly, we show that the combined effect of a dry period and restriction policies results in significant losses for farmers, which can reach $16 \%$ of gross value-added for a high but not implausible $40 \%$ limitation on water use and up to $32 \%$ for drastic restrictions of $70 \%$. The order of magnitude of these losses is in line with other studies on the Beauce aquifer, see for example Bouarfa et al. 2011 or Lejars et al. 2012a. Hence, the implementation of restriction policies comes at a cost, which our model can assess. To conclude, although restriction policies are a satisfactory way of preserving water-table levels, they can lead to serious economic losses for farmers in the short term. To avoid such losses to farmers, a policy maker could count on abundant winter recharge. In wet winters, recharge can exceed $1.5 \mathrm{~m}$ (see Bruand et al. 1997), which results in higher water-table levels the following spring than initial levels, whatever the restriction scenario considered in the current year. However, as the Beauce aquifer is characterized by low winter recharges, this scenario is rather unlikely. Our results thus imply important future challenges for policy makers in our study area.

Several extensions of this work are possible: First, we could improve the dynamic model by considering more than two periods and a more complex crop rotation system. In addition, we could introduce uncertainty and show how a farmer can cope with it. Moreover, we could assume farmers are risk averse, for example by including farmers who minimize the variance of outcomes. Finally, we could introduce different types of farmers and the interactions between them, and focus especially on how they learn about their respective behaviors. 
Author-produced version of the article published in European Review of Agricultural Economics, 2016, N44(1), p.99-120. The original publication is available at http://erae.oxfordjournals.org Doi: 10.1093/erae/jbw005

\section{References}

[1] Ali, M.H. (2011). Models in Irrigation and Water Management. In Ali, M.H. (ed.), Practices of Irrigation 83 On-farm Water Management. Springer, 379-422.

[2] Bouarfa, S., Brunel, L., Granier, J., Mailhol, J.-C., Morardet, S. and Ruelle, P. (2011). Evaluation en partenariat des stratégies d'irrigation en cas de restriction des prélèvements dans la nappe de Beauce (France). Cahiers Agricultures 20: 125-129.

[3] Bozkurt, Y., Yazar, A., Gencel, B. and Sezen, S.M. (2006). Optimum lateral spacing for drip-irrigated corn in the Mediterranean Region of Turkey. Agricultural Water Management 85: 113-120.

[4] Britz, W., Ferris, M. and Kuhn, A. (2013). Modeling water allocating institutions based on Multiple Optimization Problems with Equbilibrium Constraints. Environmental Modelling and Software 46: 196-207.

[5] Bruand, A., Creuzot, G., Quétin, P., Darthout, R., Raison, L., Courtemanche, P. and Gaillard, H. (1997). Variabilité de la recharge de la nappe de Beauce: rôle de l'irrigation et des caractéristiques du sol. Étude et Gestions des Sols 4(4): 229-245.

[6] Burt, O.R. (1967). Groundwater management under quadratic criterion functions. Water Resources Research 3(3): 673-682.

[7] Carpentier, A. and Letort, E. (2012). Accounting for heterogeneity in multicrop microeconometric models: implications for variable input demand modeling. American Journal of Agricultural Economics 94(1): 209-224.

[8] CGB, Confédération Générale des Producteurs de Betterave (ed.) (2009). La betterave en 2010, Paris, France.

[9] Coz, D. (2000). Gestion durable d'une ressource en eaux souterraines: Cas de la nappe de Beauce. La Houille Blanche 7-8: 116-121.

[10] De Frutos Cachorro, J., Erdlenbruch, K. and Tidball, M. (2014). Optimal adaptation strategies to face shocks on groundwater resources. Journal of Economic Dynamics and Control 40: 134-153.

[11] Easter, K.W., Rosegrant, M. W. and Dinar, A. (1999). Formal and informal markets for water: institutions, performance, and constraints. The World Bank Research Observer 14(1): 99-116.

[12] Erfani, T., Binions, O. and Harou, J.J. (2014). Simulating water markets with transaction costs. Water Resources Research 50: 4726-4745. 
Author-produced version of the article published in European Review of Agricultural Economics, 2016, N44(1), p.99-120. The original publication is available at http://erae.oxfordjournals.org Doi: $10.1093 /$ erae/jbw005

[13] Evers, A.J.M., Elliot, R.L. and Stevens, E.W. (1998). Integrated Decision Making for Reservoir, Irrigation, and Crop Management. Agricultural Systems 58(4): 539-554.

[14] FranceAgriMer (ed.) (2012). Les prix payés aux producteurs, résultats de l'enquête trimestrielle 2010/11. FranceAgriMer, Ministère de l'agriculture (eds), Les synthèses No.3, France.

[15] Gisser, M. and Sánchez, D.A. (1980). Competition versus optimal control in groundwater pumping. Water Resources Research 31: 638-642.

[16] Graveline, N., Loubier, S., Gleyses, G. and Rinaudo, J.-D. (2012). Impact of farming on water resources: Assessing uncertainty with Monte Carlo simulations in a global change context. Agricultural Systems 108: 29-41.

[17] Graveline, N. (2013). Adaptation de l'agriculture aux politiques de gestion de l'eau et aux changements globaux: l'apport des modèles de programmation mathématique, Thèse AgroParisTech, Paris, France.

[18] Graveline, N. and Mérel, P. (2014). Intensive and extensive margin ajustments to water scarcity in France's Cereal Belt. European Review of Agricultural Economics. doi: $10.1093 /$ erae/jbt039.

[19] Heckelei, T. (2002). Calibration and estimation of programming models for agricultural supply analysis. Habilitation thesis, Bonn University, Bonn, Germany.

[20] Heckelei, T. and Wolff, H. (2003). Estimation of contrained optimisation models for agricultural supply analysis based on generalised maximum entropy. European Review of Agricultural Economics 30(1): 27-50.

[21] Howitt, R. E. (1995). Positive Mathematical Programming. American Journal of Agricultural Economics 77(2): 329-342.

[22] Knapp, K.C. and Schwabe, K.A. (2008). Spatial Dynamics of Water and Nitrogen Management in Irrigated Agriculture. American Journal of Agricultural Economics 90(2): 524-539.

[23] Koundouri, P. (2004). Current Issues in the Economics of Groundwater Resource Management. Journal of Economic Surveys 18(5): 703-740.

[24] Lejars, C., Fusillier, J.L., Bouarfa, S., Coutant, C., Brunel, L. and Rucheton, G. (2012a). Limitation of agricultural groundwater uses in Beauce (France): What are the impacts on farms and on the food-processing sector? Irrigation and Drainage 61: 54-64. 
Author-produced version of the article published in European Review of Agricultural Economics, 2016, N44(1), p.99-120. The original publication is available at http://erae.oxfordjournals.org Doi: 10.1093/erae/jbw005

[25] Lejars, C., Fusillier, J.L., Brunel, L., Rucheton, G., Coutant, C. and Bouarfa, S. (2012b). Impact des restrictions d'eau sur les filières agro-alimentaires Nappe de Beauce, Rapport, Diatae-Irstea.

[26] Lejars, C., Fusillier, J.L., Bouarfa, S., Brunel, L., Rucheton, G., Coutant, C., Girard, X. and Golaz, F. (2012c). Impact des restrictions en eau d'irrigation sur les exploitations et les filières agricoles en Beauce. Agronomie Environnement 63 Sociétés 2(2): $139-154$.

[27] MAAF, Ministère de l'Agriculture, de l'Agroalimentaire et de la Forêt, Direction Régionale de l'Agriculture et de la Forêt (ed.) (2012). L'irrigation en Beauce. Agreste No. 2012 AR54, France.

[28] Madani, K. and Dinar, A. (2012). Cooperative institutions for sustainable common pool resource management: Application to groundwater. Ecological Economics 74: $34-45$.

[29] Mailhol, J.C., Ruelle, P., Walser, S., Schütze, N. and Dejean, C. (2011). Analysis of AET and yield predictions under surface and buried drip irrigation systems using the Crop Modele PILOTE and Hydrus-2D. Agricultural Water Management 98: 10331044.

[30] Moreaux, M. and Reynaud, A. (2006). Urban freshwater needs and spatial cost externalities for coastal aquifers: A theoretical approach. Regional Science and Urban Economics 36: 163-186.

[31] Ostrom, E. (1990). Governing the Commons - The Evolution of Institutions for Collective Action. Cambridge University Press, New York.

[32] Pérez-Blanco, C. D. and Gómez, C. M. (2014). Drought management plans and water availability in agriculture: A risk assessment model for a Southern European basin. Weather and Climate Extremes 4: 11-18.

[33] Petit, O. (2002). De la coordination des actions individuelles aux formes de l'action collective : une exploration des modes de gouvernance des eaux souterraines. Thèse de doctorat en Sciences économiques, Université de Versailles-Saint-Quentin-en-Yvelines, France.

[34] Reynaud, A. (2009). Adaptation à court et à long terme de l'agriculture au risque de sécheresse: une approche par couplage de modèles biophysiques et économiques. Revue d'études en Agriculture et Environnement 90(2): 121-154. 
Author-produced version of the article published in European Review of Agricultural Economics, 2016, N44(1), p.99-120. The original publication is available at http://erae.oxfordjournals.org Doi: 10.1093/erae/jbw005

[35] ROSACE, Réseau d'Observation des Systèmes Agricoles pour le Conseil et les Etudes, (2010). Synthèse annuelle des observations ROSACE Grandes Cultures de la campagne 2009/2010, Chambre d'Agriculture Région Centre (ed), France.

[36] Roseta-Palma, C. (2002). Groundwater Management When Water Quality Is Endogenous. Journal of Environmental Economics and Management 44: 93-105.

[37] Shah, T., Burke, J., Villholth, K., Angelica, M., Custodio, E., Daibes, F., Hoogesteger, J., Giordano, M., Girman, J., van der Gun, J., Kendy, E., Kijne, J., Llamas, R., Masiyandima, Mutsa, Margat, J., Marin, L., Peck, J., Rozelle, S., Sharma, Bharat R., Vincent, L. and Wang, J. (2007). Groundwater: a global assessment of scale and significance. In Molden, D. (Ed.), Water for food, water for life: a Comprehensive Assessment of Water Management in Agriculture. London, UK: Earthscan; Colombo, Sri Lanka: International Water Management Institute (IWMI), 395-423.

[38] Vedula, S. and Nagesh Kumar, D. (1996). An integrated model for optimal reservoir operation for irrigation of multiple crops. Water Resources Research 32(4): 1101-1108.

\section{Appendix}

Table 10: Yield-water response for wheat and average/deep soil Dry weather conditions

\begin{tabular}{lccccc}
\hline \hline Variable & Coefficient & Std.error & t Value & $\mathbf{P}>|t|$ & $\mathbf{9 5 \%}$ Conf. interval \\
\hline w & 0.0051176 & 0.0012194 & 4.20 & 0.000 & {$[0.0027036,0.0075315]$} \\
w squared & $-2.14 \mathrm{e}-06$ & $9.86 \mathrm{e}-07$ & -2.17 & 0.032 & {$[-4.09 \mathrm{e}-06,-1.87 \mathrm{e}-06]$} \\
const. & 7.144896 & 0.3032466 & 23.56 & 0.000 & {$[6.544589,7.545203]$} \\
\hline
\end{tabular}

Number of observations: 125 . Adjusted R-squared 0.3071

Normal weather conditions

\begin{tabular}{lccccc}
\hline \hline Variable & Coefficient & Std.error & t Value & $\mathbf{P}>|t|$ & $\mathbf{9 5 \%}$ Conf. interval \\
\hline w & 0.0031337 & 0.0005348 & 5.86 & 0.000 & {$[0.0020779,0.0041895]$} \\
w squared & $-1.71 \mathrm{e}-06$ & $4.76 \mathrm{e}-07$ & -3.60 & 0.000 & {$[-2.65 \mathrm{e}-06,-7.71 \mathrm{e}-07]$} \\
const. & 9.415315 & 0.1214989 & 77.49 & 0.000 & {$[9.175474,9.655156]$} \\
\hline
\end{tabular}

Number of observations: 173. Adjusted R-squared 0.2750 
Table 11: Yield-water response for barley and average/deep soil

Dry weather conditions

\begin{tabular}{lccccc}
\hline \hline Variable & Coefficient & Std.error & t Value & $\mathbf{P}>|t|$ & $\mathbf{9 5 \%}$ Conf. interval \\
\hline w & 0.004653 & 0.0007293 & 6.38 & 0.000 & {$[0.0032086,0.0060974]$} \\
w squared & $-1.99 \mathrm{e}-06$ & $6.00 \mathrm{e}-07$ & -3.32 & 0.001 & {$[-3.18 \mathrm{e}-06,-8.01 \mathrm{e}-07]$} \\
const. & 5.876013 & 0.1789212 & 32.84 & 0.000 & {$[5.521637,6.231389]$} \\
\hline
\end{tabular}

Number of observations: 119. Adjusted R-squared 0.5088

Normal weather conditions

\begin{tabular}{lccccc}
\hline \hline Variable & Coefficient & Std.error & t Value & $\mathbf{P}>|t|$ & $\mathbf{9 5 \%}$ Conf. interval \\
\hline $\mathrm{w}$ & 0.002735 & 0.0003649 & 7.50 & 0.000 & {$[0.002014,0.0034559]$} \\
w squared & $-1.25 \mathrm{e}-06$ & $3.57 \mathrm{e}-07$ & -3.50 & 0.001 & {$[-1.95 \mathrm{e}-06,-5.44 \mathrm{e}-07]$} \\
const. & 7.238088 & 0.0763662 & 94.78 & 0.000 & {$[7.087203,7.388972]$} \\
\hline
\end{tabular}

Number of observations: 154. Adjusted R-squared 0.4916

Table 12: Yield-water response for sugar beet and average/deep soil

Dry weather conditions

\begin{tabular}{lccccc}
\hline \hline Variable & Coefficient & Std.error & t Value & $\mathbf{P}>|t|$ & $\mathbf{9 5 \%}$ Conf. interval \\
\hline w & 0.0554281 & 0.0048382 & 11.46 & 0.000 & {$[0.00458902,0.064966]$} \\
w squared & -0.0000141 & $2.83 \mathrm{e}-06$ & -4.97 & 0.000 & {$[-0.0000196,-8.48 \mathrm{e}-06]$} \\
const. & 42.94781 & 1.710531 & 25.11 & 0.000 & {$[39.57571,46.31992]$} \\
\hline
\end{tabular}

Number of observations: 212. Adjusted R-squared 0.7105

Normal weather conditions

\begin{tabular}{lccccc}
\hline \hline Variable & Coefficient & Std.error & t Value & $\mathbf{P}>|t|$ & $\mathbf{9 5 \%}$ Conf. interval \\
\hline w & 0.0325382 & 0.004551 & 7.15 & 0.000 & {$[0.023583,0.0414934]$} \\
w squared & $-7.43 \mathrm{e}-06$ & $2.88 \mathrm{e}-06$ & -2.58 & 0.010 & {$[-0.0000131,-1.75 \mathrm{e}-06]$} \\
const. & 65.02174 & 1.462459 & 44.46 & 0.000 & {$[62.14399,67.89948]$} \\
\hline
\end{tabular}

Number of observations: 309. Adjusted R-squared 0.4112 